\title{
Heart and liver are infected in fatal cases of dengue: three PCR based case studies
}

\author{
S. A. M. Kularatne ${ }^{1}$, M. M. Rajapakse ${ }^{1}$, Udaya Ralapanawa ${ }^{1 *}$ (D), R. Waduge ${ }^{2}$, L. P. M. M. K. Pathirage ${ }^{1}$ and \\ R. P. V. J. Rajapakse ${ }^{3}$
}

\begin{abstract}
Background: Dengue is a global problem mainly in the tropics. Meticulous clinical management of cases has reduced the death rate significantly, but large numbers of people still succumb to severe complications of the infection. Presence of myocarditis is often overlooked leading to a poor outcome. Clinical management guidelines of dengue do not stress the importance of myocarditis as a manifestation in dengue infection. Severe hepatic dysfunction also needs emphasis.
\end{abstract}

Case presentation: We present three patients who had come to hospital on the 3rd day of fever. Two of them (case 1 and 3) were in shock on admission and case 2, who was stable on the $3^{\text {rd }}$ day, went into the critical phase and developed shock while in the hospital on the $4^{\text {th }}$ day. All three had tachycardia on admission that got worse with time. The clinical course was unstable with fluctuations in urine output and deterioration of organ function. Despite frequent monitoring and life support they survived only $2-3$ days in hospital. All three patients had myocarditis during the critical phase. In the first case, myocarditis was confirmed by troponin estimation and echocardiogram. In the second and third cases, histopathology confirmed myocarditis. Haemorrhagic necrosis of the liver was found in case 2 and 3 with exponential rise of transaminases. In all three cases, viral RNA was detected in both heart and liver tissues by PCR amplification.

Conclusions: We stress that detection of myocarditis and liver involvement in any dengue patient is important from the onset of the illness where treatment should be tailored to prevent development of hypotension. Our findings are novel as PCR and histology are rarely done on tissues of deceased dengue patients in the world. Studies are needed to find therapeutic interventions to reverse cardiac and hepatic dysfunction in dengue infection.

Keywords: Dengue, Myocarditis, Liver failure, Expanded dengue syndrome, RT-PCR, Sri Lanka

\section{Background}

Dengue is a global problem, mainly in the tropics, and travelers visiting endemic regions are at risk of contracting the infection [1-3]. Meticulous clinical management of cases has reduced the death rate significantly, but large numbers of people succumb to severe complications of the infection [4]. Sri Lanka experienced the worst dengue epidemic in mid-2017 with a total case load of the year amounting to 185,000 cases, with more than 400 deaths [5]. At institution level and centrally at the Ministry of Health, these unfortunate deaths are being reviewed in order

\footnotetext{
* Correspondence: udayapralapanawa@yahoo.com

${ }^{1}$ Department of Medicine, Faculty of Medicine, University of Peradeniya,

Peradeniya, Sri Lanka

Full list of author information is available at the end of the article
}

to improve case management and to understand the contributory factors responsible for death. However, despite improvement of necessary infrastructure and guideline-based management, dengue infection still causes deaths [6]. The main pathology of dengue haemorrhagic fever is plasma leak from capillaries, where all kinds of cytokines are involved,but is amenable to meticulous fluid management $[4,6]$. Moreover, WHO recognizes the expanded dengue syndrome to explain uncommon complications of the infection [7]. The majority of patients recover from the infection, if plasma leak is the sole pathology. Such a notion in the clinician's mind tends to overlook the concomitant vital organ dysfunction that is present in some cases of dengue. In these three case studies, we aim to demonstrate the presence of virus in the organ 
tissue at necropsy examination and to collate those findings with the clinical and laboratory manifestations prior to death to show evidence of dengue infection in the heart and lungs.

\section{Case presentation}

\section{Case 1}

A 34-year-old male presented to the THP on 11th May 2017 with a 3-day history of fever, arthralgia, backache, headache and skin flush. He had no cough, abdominal pain or diarrhoea. On admission, he was ill looking and had postural giddiness and cold peripheries. Blood pressure was $80 / 50 \mathrm{mmHg}$ and pulse rate was 98 beats/min. Resuscitation was attempted with rapid infusion of 500 $\mathrm{ml}$ of normal saline followed by continuation normal saline infusion. His blood pressure (BP) picked up to 100/ $70 \mathrm{mmHg}$, but he remained oliguric over the next $12 \mathrm{~h}$. Dextran 40 colloid $500 \mathrm{ml}$ bolus infusion was given to raise the $\mathrm{BP}$ and to produce more urine. Twelve hours later, he developed generalized convulsions and needed immediate intubation and assisted ventilation in the Intensive Care Unit (ICU). Chest radiograph showed bilateral lung shadows suggestive of pulmonary oedema. Other investigations are shown in Table 1. In the ICU, at $3 \mathrm{PM}, \mathrm{BP}$ was $130 / 80 \mathrm{mmHg}$ and pulse rate was 130 beats/min. However, at $3.30 \mathrm{PM}$, pulse rate was 160 beats /min, and BP dropped to $97 / 53 \mathrm{mmHg}$. The patient had central cyanosis, cold peripheries, feeble peripheral pulses and the haematocrit (HCT) rose to 55\% requiring more Dextran 40 infusion.

On morning of the fifth day at $5 \mathrm{AM}, \mathrm{HCT}$ and haemoglobin dropped to $28 \%$ and $9 \mathrm{~g} / \mathrm{dl}$ respectively without any obvious bleeding. With transfusion of one unit of blood, $\mathrm{BP}$ rose to $130 / 95 \mathrm{mmHg}$. With further transfusion HCT and urine output improved. Two dimensional echocardiogram showed global left ventricular hypokinesia with an ejection fraction of $40 \%$. Cardiac troponintitre was high. From noon, the BP was falling - 80/50 $\mathrm{mmHg}$ and tachycardia persisted that needed continuous inotrope infusion. Despite meticulous management, the patient developed cardiac arrest and resuscitation failed.

\section{Case 2}

A 36-year-old male suffering from type 2 diabetes for 3 years was transferred to the Teaching Hospital, Kandy on the 15th July, 2017 with a 3-day history of fever and arthralgia.On admission he was febrile and BP was 130/ 80 and pulse rate was 90 beats per min. Lungs were clear and abdomen was soft with no hepatomegaly. Initial investigations revealed WBC of $3 \times 10^{9} / \mathrm{l}$, platelets of $63 \times 10^{9} / 1$ and HCT of $45 \%$. On day 1 of admission, his basic clinical parameters were normal and urine output was adequate throughout the day. On the next day, ultrasound scan examination of abdomen showed evidence of early plasma leaking, thus initiating critical phase monitoring from $9 \mathrm{am}$ on 16th July. At this point his $\mathrm{BP}$ was $100 / 70 \mathrm{mmHg}$ and $\mathrm{HCT}$ was $45 \%$. His WBC was $3.7 \times 10^{9} / \mathrm{l}$, platelet count was $34 \times 10^{9} / \mathrm{l}$. His alanine transaminase (ALT) and aspartate transaminase (AST) were $383 \mathrm{U} / \mathrm{l}$ and $463 \mathrm{U} / \mathrm{l}$ respectively.

From the onset of the critical phase, the patient had tachycardia which persisted. He had satisfactory urine output initially, but his HCT continued to increase. At about $7 \mathrm{pm}$, a Dextran- 40 colloid $500 \mathrm{ml}$ bolus was given, but at midnight the urine output started dropping to a level of $35 \mathrm{ml} / \mathrm{h}$. Thus, another bolus of $250 \mathrm{ml}$ of dextran-40 was given. Meanwhile, the patient developed melaena, and $500 \mathrm{ml}$ of whole blood was transfused. As the patient developed lactic acidosis, sodium bicarbonate infusion was given.

The patient was transferred to the ICU, Teaching hospital, Peradeniya (THP) at 3 am of 17 th July while managing the critical phase into the 18th hour. On admission, blood pressure was $125 / 91 \mathrm{mmHg}$ which rapidly dropped to $100 / 80 \mathrm{mmHg}$ and the peripheries were cold to touch. The patient was conscious and rational. The urine output dropped to $20 \mathrm{ml} / \mathrm{h}$. Pulse rate remained at 140 beats $/ \mathrm{min}$. Auscultation of the lungs revealed reduced breath sounds with fine crepitations in both lungs. Melaena was present on rectal examination. Arterial blood gasses showed lactic acidosis. Ultrasound examination of abdomen showed a significant amount of ascites. The patient was given two $250 \mathrm{ml}$ boluses of dextran-40. The investigations are shown in Table 1. By about $7 \mathrm{AM}$, the patient became anuric with BP of $99 / 65 \mathrm{mmHg}$ and HCT was $50 \%$. The patient was transfused with 3 units of blood within the next $2 \mathrm{~h}$ but he remained anuric. By $9 \mathrm{AM}$, the patient was confused and disoriented and had cold peripheries with sluggish capillary refilling. He was intubated and ventilated electively. At $1.20 \mathrm{pm}$ the patient developed bradycardia followed by cardiac arrest and resuscitation was unsuccessful.

\section{Case 3}

A 40-year-old female with a history of bronchial asthma for 17 years, presented to the THP with fever of 3 days duration associated with vomiting and postural giddiness on 22nd July 2017. On admission, pulse rate was 108 beats $/ \mathrm{min}$ and blood pressure was unrecordable. Ultrasound scan of the abdomen showed evidence of fluid leaking. The onset of critical phase was calculated $8 \mathrm{~h}$ backward and prompt resuscitation was attempted. Despite fluid resuscitation tachycardia persisted with reduced urine output. On admission her ALT was $1365 \mathrm{U} / \mathrm{l}$ and AST was $2999 \mathrm{U} / \mathrm{l}$. Serum albumin was $30.8 \mathrm{mg} / \mathrm{dl}$ and serum creatinine was $84 \mu \mathrm{mol} / \mathrm{l}$. Her INR was 1.38 . Serum amylase was $37 \mathrm{U} / \mathrm{L}$.

On the evening of the same day she complained of abdominal pain with tenderness of the right hypochondrium. 
Table 1 Summary of important clinical and laboratory data of 3 fatal cases of dengue with the list of complications

\begin{tabular}{|c|c|c|c|c|c|c|}
\hline \multicolumn{2}{|c|}{ Description of case } & \multirow{2}{*}{$\begin{array}{l}\text { Clinical status on admission } \\
\text { and subsequently }\end{array}$} & \multicolumn{2}{|l|}{ Investigations } & \multirow[t]{2}{*}{ Complications } & \multirow{2}{*}{$\begin{array}{l}\text { Duration of illness } \\
\text { from onset to death }\end{array}$} \\
\hline No & Age/Gender & & Test & Results & & \\
\hline \multirow[t]{10}{*}{1} & \multirow[t]{10}{*}{$34 / M$} & Fever 3 days & WBC & $3.5 \times 10^{9} / 1$ & Persistent hypotension & \multirow[t]{10}{*}{5 days } \\
\hline & & Postural giddiness & Platelets & $28 \times 10^{9} / 1$ & Fluid overload & \\
\hline & & Cold peripheries & Creatinine & $193 \mu \mathrm{mol} / \mathrm{l}$ & Pulmonary oedema & \\
\hline & & BP: $80 / 50 \mathrm{mmHg}$ & CRP & $320 \mathrm{mg} / \mathrm{l}$ & Left ventricular- & \\
\hline & & Pulse rate $98 / \mathrm{min}$ & $\mathrm{ALT}$ & $73 \mathrm{U} / \mathrm{L}$ & hypokinesia & \\
\hline & & Convulsions & AST & $98 \mathrm{U} / \mathrm{L}$ & Hypoxaemia & \\
\hline & & \multirow[t]{4}{*}{ Assisted ventilation } & Troponin I & $0.29 \mathrm{ng} / \mathrm{ml}$ & Sepsis & \\
\hline & & & $\mathrm{PH}$ & 7.1 & Lactic acidosis & \\
\hline & & & Pco2 & $44 \mathrm{mmHg}$ & Bleeding & \\
\hline & & & $\mathrm{PaO} 2$ & $61 \mathrm{mmHg}$ & Renal failure & \\
\hline \multirow[t]{10}{*}{2} & \multirow[t]{10}{*}{$36 / M$} & Type 2 diabetes & WBC & $3.7 \times 10^{9} / 1$ & Erratic critical phase & 6 days \\
\hline & & Fever 3 days & Platelets & $34 \times 10^{9} / 1$ & Undue tachycardia & \\
\hline & & BP $130 / 80 \mathrm{mmHg}$ & Creatinine & $82.5 \mu \mathrm{mol} / \mathrm{l}$ & Hypotension & \\
\hline & & Pulse rate $90 / \mathrm{min}$ & Blood sugar & 233 mg/dl & Fulminant hepatic & \\
\hline & & Critical phase on & ALT (day- 3) & $383 \mathrm{U} / \mathrm{L}$ & failure & \\
\hline & & \multirow{5}{*}{$\begin{array}{l}\text { 4th day with pleural effusion, } \\
\text { tachycardia and low BP } 100 \mathrm{mmHg} \\
\text { Melaena, Reduced urine out put }\end{array}$} & $($ day-4) & $4905 \mathrm{U} / \mathrm{L}$ & Gl- bleeding & \\
\hline & & & AST (day-3) & $463 \mathrm{U} / \mathrm{L}$ & Acute kidney injury & \\
\hline & & & $($ day-4) & $9371 \mathrm{U} / \mathrm{L}$ & Lactic acidosis & \\
\hline & & & INR (day-5) & $>5$ & & \\
\hline & & & PH (day-5) & 7.32 & & \\
\hline \multirow[t]{9}{*}{3} & \multirow[t]{9}{*}{$40 / F$} & Bronchial asthma & WBC & $8.2 \times 10^{9} / 1$ & Profound shock on & \multirow[t]{9}{*}{6 days } \\
\hline & & Fever 4 days & Platelet & $28 \times 10^{9} / 1$ & admission & \\
\hline & & Vomiting, shock & $\mathrm{HCt}$ & 37 & Pleural effusions & \\
\hline & & Cold peripheries & Creatinine & $84 \mu \mathrm{mol} / \mathrm{l}$ & Fulminant hepatic & \\
\hline & & BP - un-recordable & Albumin & $30.8 \mathrm{~g} / \mathrm{l}$ & failure & \\
\hline & & Pulse-108/ min & ALT(day-4) & $1365 \mathrm{U} / \mathrm{L}$ & Encephalopathy & \\
\hline & & US-Ab: fluid leak & (day-7) & $2590 \mathrm{U} / \mathrm{L}$ & & \\
\hline & & Abdominal pain & AST (day-4) & 2999 U/L & & \\
\hline & & Melaena Confusion & $($ day-5) & $6812 \mathrm{U} / \mathrm{L}$ & & \\
\hline
\end{tabular}

She passed melaena stools. She had tachypnoea and blood gasses revealed acidosis. A small right sided pleural effusion was also present. She was transfused with one unit of whole blood. By the next morning her abdominal pain and postural symptoms increased and she developed mild icterus. She had tachycardia, but the blood pressure was maintained and urine output was satisfactory. She then developed ascites and bilateral pleural effusions. The next AST was $3661 \mathrm{U} / \mathrm{l}$ and ALT was $1579 \mathrm{U} / \mathrm{l}$. By the evening her oxygen saturation dropped despite administering $100 \%$ oxygen. Subsequent AST and ALT were $8543 \mathrm{U} / \mathrm{l}$ and $2981 \mathrm{U} / \mathrm{l}$ respectively. The serum amylase was $48 \mathrm{U} / \mathrm{l}$ and serum creatinine was $105 \mu \mathrm{mol} / \mathrm{l}$.

Towards the latter part of the critical phase the HCT started falling and the urine output declined to $25 \mathrm{ml} / \mathrm{h}$. Several units of blood, FFP, and human albumin were infused to maintain the HCT. The patient rapidly developed difficulty in breathing with bilateral moderate pleural effusions. However, her AST and ALT levels reduced to $3661 \mathrm{U} / 1$ and $2685 \mathrm{U} / \mathrm{l}$. On 24th July, the critical phase monitoring was over, but the patient gradually became confused and disoriented. She had high fever and oral bleeding but her other vital parameters and urine output were satisfactory. There were crepitations all over the lung fields and she needed assisted ventilation in the ICU. She died on the 2 nd day in the ICU.

\section{Discussion and conclusions}

All three patients entered hospital on the 3rd day of fever.Two of them,cases 1 and 3, were in shock on admission and case 2, who was stable on admission on the 3rd day of fever,went into critical phase and shock while 
in the hospital on the 4th day. All three had tachycardia on admission that increased with time. The clinical course was unstable with fluctuations in urine output and deterioration of organ function. With very close monitoring and intense life support they lived only 2-3 days in the hospital. All three patients had myocarditis complicating the critical phase. In the first case, myocarditis was confirmed by cardiac troponin estimation and echocardiogram. In the second and third cases, post mortem histopathology confirmed myocarditis (Table 2, Fig. 1).PCR amplification was used to demonstrate the presence of dengue viral RNA in the myocardium in all three cases. The liver involvement is more marked in case 3 as evident by very high levels of hepatic transaminases. Case 2 and 3 had extensive haemorrhagic necrosis of the liver (Table 2, Fig. 2). In all three cases, viral RNA was detected by PCR in the liver. Moreover, viral RNA was detected in many tissues of these patients.

Postmortem studies are seldom reported in the world despite many dengue deaths. Further, histology and PCR studies of tissues of deceased victims are hardly happening despite availability of technology. Therefore, organ involvement in dengue infection has not been fully understood. This study shows extent of organ involvement in dengue and how it collates with the clinical manifestations in severe cases of dengue. There is a possibility that dengue virus infected blood cells entrapped in the organs would have given positive PCR results. However, taking clinical evidence of organ dysfunction, biochemical derangements and histology together, it is most likely that dengue virus could infect the organs.

Literature to support the existence of myocarditis in dengue infection has been available for more than a decade [8-15]. However, clinical management guidelines have given only little importance to myocarditis as a manifestation in dengue infection [6, 15]. In 2005, clinical experience in managing a large series of dengue cases with myocarditis in Sri Lanka was published where the causative serotype was DEN $3[9,13,14]$. Histopathological evidence of myocarditis was also found in 2009 [13]. A traveler returning from the Dominican Republic developing myocarditis has been published in 2014 [8]. Even though, there have been many deaths due to dengue, the literature available on necropsy studies dealing with detection of virus in tissues and related histopathology is scarce [16-21]. This deficit has curtailed critical analysis and identification of the true contributory causes for deaths. Clinicians are trapped in a straitjacket of orthodox thinking of clinical management of dengue where some patients die due to irreversible shock. It has been observed that fluid overload has contributed to most dengue deaths, like in case 1 in this series. In pure fluid leaking DHF, fluid overload does not occur if the cardiac status is normal. However, if myocarditis is present, the heart naturally fails when fluid is given in excess. The presence of tachycardia and development of shock early in the disease should sound the alarm of myocarditis. To prevent deaths, early detection

Table 2 Detection of Dengue virus RNA in different tissue samples obtained at necropsy examination and respective gross and microscopic changes in tissues of fatal cases of dengue

\begin{tabular}{|c|c|c|c|c|c|c|}
\hline \multirow[t]{2}{*}{ Tissue } & \multicolumn{2}{|c|}{ Case 1} & \multicolumn{2}{|c|}{ Case 2} & \multicolumn{2}{|c|}{ Case 3} \\
\hline & PCR & Macroscopy & PCR & Histology & PCR & Histology \\
\hline Brain & - & & + & Normal & - & Normal \\
\hline Lungs & + & Congested, Haemorrhagic & * & Congested capillaries & + & $\begin{array}{l}\text { Pulmonary oedema, capillary } \\
\text { congestion in interstitium }\end{array}$ \\
\hline Heart & + & Petechial haemorrages & + & $\begin{array}{l}\text { Interstitial oedema with infiltration } \\
\text { of neutrophils and lymphocytes }\end{array}$ & + & $\begin{array}{l}\text { Marked interstitial oedema, lymphocytic } \\
\text { infiltration in endomyseum }\end{array}$ \\
\hline Liver & + & Congested & + & Extensive haemorrhagic necrosis & + & $\begin{array}{l}\text { Submassive necrosis, haemorrhagic } \\
\text { necrosis }\end{array}$ \\
\hline Kidney & + & & + & Acute tubular necrosis & - & Acute tubular necrosis \\
\hline Spleen & - & & - & $\begin{array}{l}\text { Expansion of red pulp, } \\
\text { extravasations of red cells }\end{array}$ & - & $\begin{array}{l}\text { Expansion of red pulp with } \\
\text { haemorrhage }\end{array}$ \\
\hline Adrenal gland & * & & * & & + & Early autolysis \\
\hline Pancreas & $*$ & & * & & + & Early autolysis \\
\hline Intestines & + & & * & & & \\
\hline Muscles & * & & + & $\begin{array}{l}\text { Occasional fibre necrosis, } \\
\text { inflammation }\end{array}$ & + & \\
\hline Skin & + & & * & & * & \\
\hline Blood & + & & * & & * & \\
\hline
\end{tabular}

(+) detection of dengue (DEN 2) RNA in tissues, (--) Dengue RNA not detected, $\left(^{*}\right)$ Not tested as tissues samples were not available. In Case 1 , histology of tissues were not done 


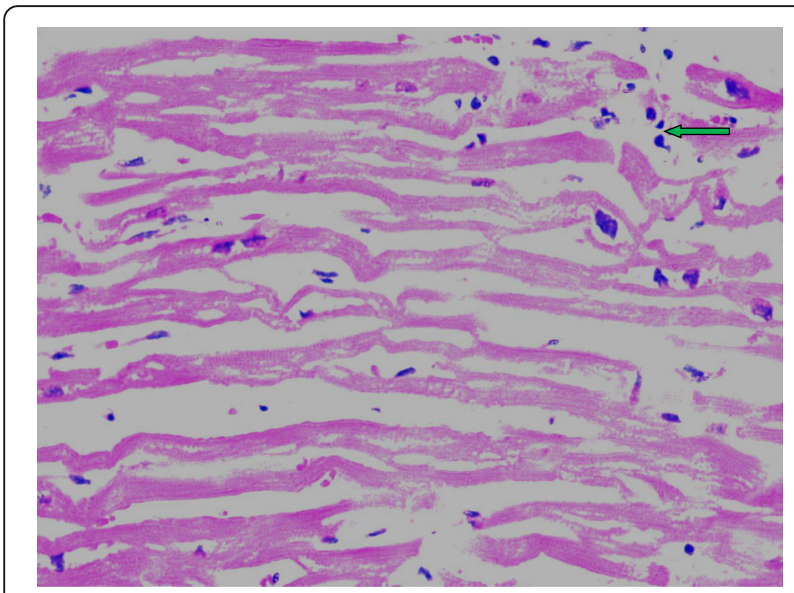

Fig. 1 Heart muscle $\times 400$ inflammatory cell infiltration shown in arrow

of myocarditis is essential to institute extra precautions needed in management $[9,13,14]$.

Hepatic involvement in dengue has been addressed in guidelines and literature $[6,7,22,23]$. However, hepatic involvement has been ascertained by rising transaminases and in extreme cases development of fulminant hepatic failure. Very often, the pathophysiology that leads to hepatic dysfunction remains unknown. Speculation of ischemic hepatic damage during the critical phase is often entertained. In 2014, we demonstrated extensive haemorrhagic necrosis of liver in a necropsy study along with detection of viral RNA in liver tissue [23]. In the present case series, we found similar findings. In general, all cases of dengue infection have elevated transaminases at different levels [7, 24-26]. In some cases, elevation of transaminases is very high [24]. This suggests that the dengue virus infects the liver in virtually all cases, rarely causing severe hepatitis. Minimizing liver damage in dengue is a problem that needs resolving: some clinicians use $\mathrm{N}$ acetyl cystine infusions on

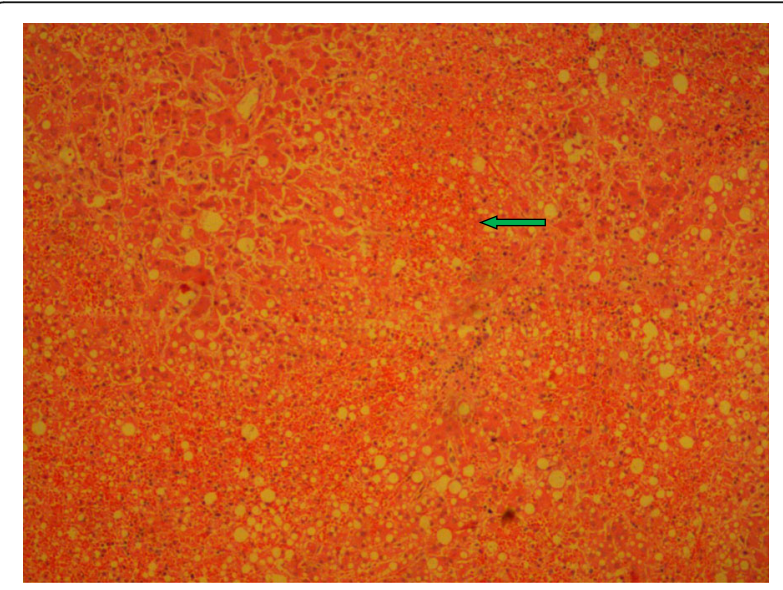

Fig. 2 Liver $\times 100$ bringing necrosis shown in arrow a regular basis when hepatic transaminases are high $[27,28]$. Studying these three cases suggests that the dengue virus could infect any tissue in the body even skin, muscles and intestine (Table 2). This is usually reflected in the clinical manifestations of dengue e.g. muscle pain, skin rashes, abdominal pain, diarrhoea etc. It is of interest that in this study viral RNA was not detected in the spleen. Clinically, these three cases demonstrate multiple organ dysfunction, metabolic abnormalities, sepsis and bleeding along with persistent hypotension contributing to death. Once the balance of critical parameters tilts towards deterioration, it becomes irreversible and death becomes inevitable despite giving the best of care and life support. We can extrapolate our findings to explain most of the fatalities in dengue in Sri Lanka and even the world over. Therefore, we stress that detection of myocarditis and liver involvement in any dengue patient is important from the onset of the illness where treatment should be tailored to prevent development of hypotension. Studies are needed to find therapeutic interventions to revert cardiac and hepatic dysfunction in dengue infections.

\section{Abbreviations}

ALT: Alanine transaminase; AST: Aspartate transaminase; CRP: Creactive protein; HCT: Haematocrit; ICU: Intensive Care Unit; PCR: Polymerase chain reaction; WBC: White blood cells

\section{Acknowledgements}

We wish to express our sincere thanks to Dr. Malik Fernando for copyediting the manuscript.

\section{Funding}

Not applicable

\section{Availability of data and materials}

Not applicable

\section{Authors' contributions}

SAMK, UR and LPMMKP managed patients. RW and RPVJR did histology and PCR respectively. MMR collected the data and coordinated the study. All authors did intellectual contribution and participated in drafting the manuscript. All authors read and approved the final manuscript.

\section{Ethics approval and consent to participate}

Not applicable

\section{Consent for publication}

Postmortem examinationsin all three cases were performed as a legal requirement and the tissues were harvested for histology and viral studies with the consent of the next-of-kin in each case. We confirm that all procedures carried out on patients' tissues and blood samples including PCR were part of the routine postmortem examination. Written informed consent was obtained from the patients' relatives for publication of these case reports and any accompanying images. A copy of the written consent is available for review by the Editor-in-Chief of this journal.

\section{Competing interests}

The authors declare that they have no competing interests. 


\section{Publisher's Note}

Springer Nature remains neutral with regard to jurisdictional claims in published maps and institutional affiliations.

\section{Author details}

'Department of Medicine, Faculty of Medicine, University of Peradeniya, Peradeniya, Sri Lanka. ${ }^{2}$ Department of Pathology, Faculty of Medicine, University of Peradeniya, Peradeniya, Sri Lanka. ${ }^{3}$ Department of Veterinary Pathobiology, Faculty of Veterinary Medicine and Animal Science, University of Peradeniya, Peradeniya, Sri Lanka.

Received: 27 April 2018 Accepted: 10 December 2018

Published online: 19 December 2018

\section{References}

1. Bhatt $S$, Gething PW, Brady OJ, Messina JP, Farlow AW, Moyes $C L$, Drake JM, Brownstein JS, Hoen AG, Sankoh O, Myers MF, George DB, Jaenisch T, Wint GR, Simmons CP, Scott TW, Farrar JJ, Hay SI. The global distribution and burden of dengue. Nature. 2013;496(7446):504-7. https://doi.org/10.1038/nature12060 Epub 2013 Apr 7.

2. Dengue.WHO. http://www.who.int/ith/diseases/dengue/en/. Accessed 15 Apr 2018.

3. Wilder-Smith A. Dengue infections in travellers. Paediatr Int Child Health. 2012;32(s1):28-32. https://doi.org/10.1179/2F2046904712Z.00000000050.

4. Kularatne SAM. Dengue fever. BMJ. 2015;351:h4661.

5. Weekly epidemiological Report, Epidemiology Unit, Ministry of Health, Sri Lanka. 2018;45:2. http://www.epid.gov.Ik/web/images/pdf/wer/2018/vol_45_ no_02-english.pdf. Accessed 15 Apr 2018.

6. Ministry of Health - Sri Lanka, National Guidelines on Management of Dengue Fever \& Dengue Haemorrhagic Fever In Adults, Revised and expanded edition November 2012. http://www.epid.gov.Ik/web/images/pdf/ Publication/guidelines_for_the_management_of_df_and_dhf_in_adults.pdf. Accessed 15 Apr 2018.

7. Ralapanawa DMPUK, Kularatne SAM. Current Management of Dengue in adults: a review. Int Med J Malays. 2015;14(1):29-42.

8. Zea D, Foley $\mathrm{K}$, Case Report CJ. Myocarditis in a traveler returning from the Dominican Republic:an unusual presentation of dengue fever. Am J Trop Med Hygine. 2014;91(1):156-8. https://doi.org/10.4269/ajtmh.13-0637.

9. Kularatne S, Pathirage MMK, Medagama UAB, Gunasena S, Gunasekera MB. Myocarditis in three patients with dengue virus type DEN 3 infection. Ceylon Med J. 2009:51(2):75-6. https://doi.org/10.4038/cmj.v51i2.1362.

10. Sane S, Saulova A, McLaren R, White H. A fatal case of primary dengue infection with myocarditis and cerebral oedema. AMJ. 2015;8(9):299-303. https://doi.org/10.4066/AMJ.2015.2489.

11. Ku Y-H, Yu W-L. Case Report-Fatal dengue myocarditis despite the use of Extracoporal membrane oxygenation. Case Rep Infect Dis. 2016. https://doi. org/10.1155/2016/5627217.

12. Torres AF, Braga DN, Muniz F, Mendonca C, Olivera DN, de Souza ET, Bruke A, Tavora F. Lymphocytic myocarditis at autopsy in patients with dengue fever. Braz J Infect Dis. 2013;17(5):619-21. https://doi.org/10. 1016/j.bjid.2013.03.009.

13. Weerakoon GAD, Kularatne SAM, Edussuriya DH, Kodikara KAS, Gunathilake PGL, Pinto VG, Seneviratne GS. Histopathological diagnosis of myocarditis in a dengue outbreak in Sri Lanka, 2009. BMC Res Notes. 2011;4:268. https:// doi.org/10.1186/1756-0500-4-268.

14. Kularatne SAM, Pathitage MMK, Kumarasiri PVR, Gunasena S, Mahindawansa SI. Cardiac complications of a dengue fever outbreak in Sri Lanka, 2005. Trans R Soc Tro Med Hyg. 2007;101:804-8. https://doi.org/10.1016/j.trstmh. 2007.02.021.

15. Lim SMS, Hoo FK, WAW S. A case of dengue haemorrhagic fever with myocarditis and complete heart block. Rawal Medical Journal. 2014;39(1):104-6

16. Bhamarapravati N, Tuchinda P, Boonyapaknavik V. Pathology of Thailand haemorrhagic fever: a study of 100 autopsy cases. Ann Trop Med Parasitol. 1967;61(4):500-10.

17. Fresh JW, Reyes V, Clarke EJ, Uylangco CV. Philippine hemorrhagic fever: a clinical, laboratory, and necropsy study. J Lab Clin Med. 1969;73(3):451-8.

18. Couvelard A, Marianneau P, Bedel C, Drouet MT, Vachon F, Hénin D, Deubel $\checkmark$. Report of a fatal case of dengue infection with hepatitis: demonstration of dengue antigens in hepatocytes and liver apoptosis. Hum Pathol. 1999; 30(9):1106-10.
19. Rosen L, Drouet MT, Deubel V. Detection of dengue virus RNA by reverse transcription-polymerase chain reaction in the liver and lymphoid organs but not in the brain in fatal human infection. Am J Trop Med Hyg. 1999; 61(5):720-4.

20. Rathi KR, Arora MM, Sahai K, Tripathi S, Singh SP, Raman DK, Anand KB. Autopsy findings in fatal dengue haemorrhagic fever - 06 cases. Med J Armed Forces India. 2013;69(3):254-9. https://doi.org/10.1016/j.mjafi.2012.08.021.

21. Aye KS, Charngkaew K, Win N, Wai KZ, Moe K, Punyadee N, Thiemmeca S, Suttitheptumrong A, Sukpanichnant S, Prida M, Halstead SB. Pathologic highlights of dengue hemorrhagic fever in 13 autopsy cases from Myanmar. Hum Pathol. 2014:45(6):1221-33. https://doi.org/10.1016/j.humpath.2014.01.022.

22. World Health Organization. Dengue Guidelines For Diagnosis, Treatment, Prevention And Control, New edition 2009. http://www.who.int/tdr/ publications/documents/dengue-diagnosis.pdf.

23. Kularatne SA, Imbulpitiya IV, Abeysekera RA, Waduge RN, Rajapakse RP, Weerakoon KG. Extensivehaemorrhagic necrosis of liver is an unpredictable fatal complication in dengue infection: a postmortem study. BMC Infect Dis. 2014;14:141. https://doi.org/10.1186/1471-2334-14-141.

24. Ageep A. Degree of liver injury in dengue virus infection. J Gen Mol Virol. 2012;4(October):1-5. https://doi.org/10.5897/JGMV11.023.

25. Samanta J. Dengue and its effects on liver. World J Clin Cases. 2015;3:125. https://doi.org/10.12998/wjcc.v3.i2.125.

26. Fernando S, Wijewickrama A, Gomes L, Punchihewa CT, Madusanka SDP, Dissanayake H, Jeewandara C, Peiris H, Ogg GS, Malavige GN. Patterns and causes of liver involvement in acute dengue infection. BMC Infect Dis. 2016; 16:319. https://doi.org/10.1186/s12879-016-1656-2.

27. Habaragamuwa BWP, Dissanayaka P. N-acetylcystein in dengue associated severe hepatitis. Indian J Crit Care Med. 2014;18(3):181-2. https://doi.org/10. 4103/0972-5229.128712.

28. Kumarasena RS, Senanayake SM, Sivaraman K, de Silva AP, Dassanayake AS, Premaratna R, Wijesiriwardena B, de Silva HJ. Intravenous $\mathrm{N}$-acetylcysteine in dengue-associated acute liver failure. Hepatol Int. 2010;4(2):533-4. https:// doi.org/10.1007/s12072-010-9176-4 Published online 2010 May 28.

\section{Ready to submit your research? Choose BMC and benefit from:}

- fast, convenient online submission

- thorough peer review by experienced researchers in your field

- rapid publication on acceptance

- support for research data, including large and complex data types

- gold Open Access which fosters wider collaboration and increased citations

- maximum visibility for your research: over $100 \mathrm{M}$ website views per year

At BMC, research is always in progress.

Learn more biomedcentral.com/submissions 